Article

\title{
An Unusual Diterpene-Enhygromic Acid and Deoxyenhygrolides from a Marine Myxobacterium, Enhygromyxa sp.
}

\author{
Tomohiko Tomura ${ }^{1}$, Shiori Nagashima ${ }^{1}$, Satoshi Yamazaki ${ }^{1}$, Takashi Iizuka ${ }^{2}$, Ryosuke Fudou ${ }^{3}$ \\ and Makoto Ojika ${ }^{1, *}$ \\ 1 Graduate School of Bioagricultural Sciences, Nagoya University, Chikusa-ku, Nagoya 464-8601, Japan; \\ ttomura@agr.nagoya-u.ac.jp (T.T.); nagashima.shiori@d.mbox.nagoya-u.ac.jp (S.N.); \\ yamazaki.satoshi@a.mbox.nagoya-u.ac.jp (S.Y.) \\ 2 Institute for Innovation, Ajinomoto Co., Inc., Kawasaki, Kanagawa 210-8681, Japan; \\ takashi_iizuka@ajinomoto.com \\ 3 R \& D Planning Department, Ajinomoto Co., Inc., Chuo-ku, Tokyo 104-8315, Japan; \\ ryosuke_fudou@ajinomoto.com \\ * Correspondence: ojika@agr.nagoya-u.ac.jp; Tel.: +81-52-789-4116
}

Academic Editor: Yoshihide Usami

Received: 1 March 2017; Accepted: 4 April 2017; Published: 6 April 2017

\begin{abstract}
Three new compounds, enhygromic acid (1) and deoxyenhygrolides A (2) and B (3), were isolated from a marine myxobacterium, Enhygromyxa sp. Compound $\mathbf{1}$ was found to be an acrylic acid derivative with a rare polycyclic carbon skeleton, decahydroacenaphthylene, by spectroscopic analyses. Compounds 2 and 3 were deoxy analogs of the known $\gamma$-alkylidenebutenolides, enhygrolides. Compound 1 exhibited cytotoxicity against B16 melanoma cells and anti-bacterial activity against Bacillus subtilis, and enhanced the NGF-induced neurite outgrowth of PC12 cells.
\end{abstract}

Keywords: marine myxobacterium; diterpene; NGF-enhancing activity; cytotoxicity; antibacterial activity

\section{Introduction}

Myxobacteria are unique $\delta$-proteobacteria that glide and aggregate to form swarms and multicellular fruiting bodies [1]. Myxobacteria were recently recognized as potential sources of novel secondary metabolites such as polyketides and non-ribosomal peptides as well as their hybrid compounds [2,3]. Marine-derived myxobacteria are especially attractive [4] because their polyketide synthase gene sequences are unique [5], although they are more difficult to cultivate compared to their terrestrial counterparts. In recent years, some bioactive compounds were discovered from marine myxobacteria including haliangicins [6,7] and haliamide [8] from Haliangium ochraceum; miuraenamides produced by Paraliomyxa miuraensis [9,10]; and salimabromides [11], salimyxins [12], and enhygrolides [12] produced by Enhygromyxa salina [13]. Our group has been searching for new myxobacteria species in marine environment for decades [14]. Our research on marine myxobacterial secondary metabolites led to the discovery of three new compounds, enhygromic acid (1) and deoxyenhygrolides A (2) and B (3) (Figure 1), from a new species within the genus Enhygromyxa. Here, we report the isolation, structural elucidation, and biological activities of these compounds, one of which is an acrylic acid derivative with a rare tricyclic carbon skeleton. 


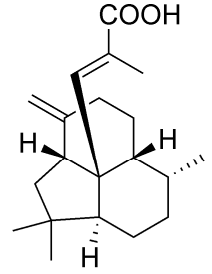

enhygromic acid (1)<smiles>CC(C)CC1=C(Cc2ccccc2)C(=O)OC1=Cc1ccccc1</smiles>

$Z$ : deoxyenhygrolide $A$ (2)

$E$ : deoxyenhygrolide $B(3)$

Figure 1. Structures of 1-3.

\section{Results and Discussion}

\subsection{Isolation and Structural Elucidation of 1-3}

Enhygromyxa sp. SNB-1 was found to be a new species based on the $16 \mathrm{~S}$ rRNA gene sequence (97\% similarity to the closest type strain) and tentatively designated as Enhygromyxa niigataensis (Figure 2).

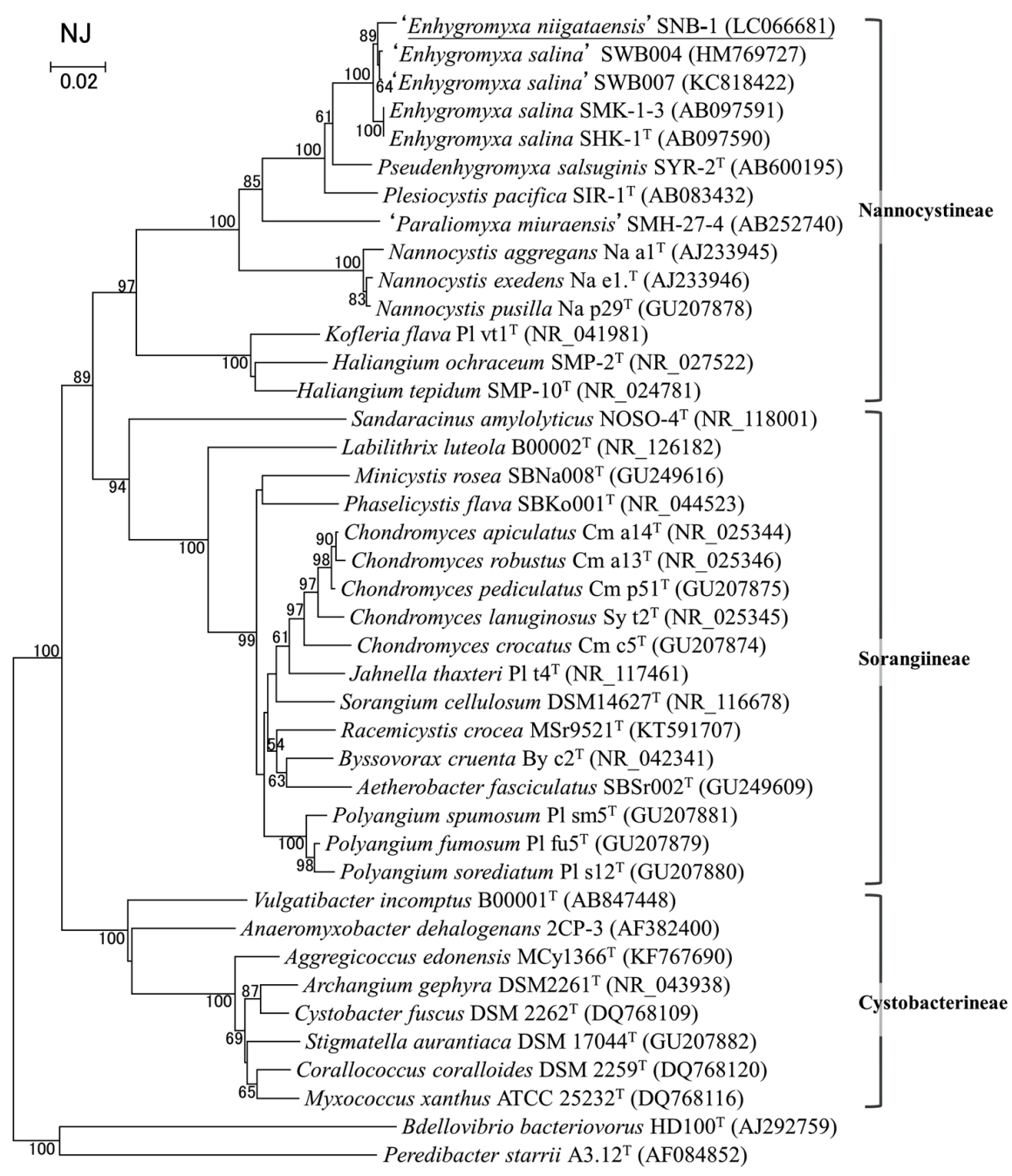

Figure 2. Phylogenetic tree of myxobacteria. Neighbor-joining (NJ) tree based on $16 \mathrm{~S}$ rRNA gene sequences shows the positions of Enhygromyxa sp. SNB-1 (tentative name: E. niigataensis, top) in the order Myxococcales. The bar represents $20 \mathrm{nt}$ substitutions per 1000 sites. Bootstrap values (>50\%) based on 1000 replications are shown at branch nodes. Three suborders in the order Myxococcales are also indicated. The two species at the bottom were used as outgroups. 
The strain was cultured for three weeks in VY /4-SWS ( $2 \% \mathrm{NaCl})$ liquid medium supplemented with $100 \mathrm{mM}$ sodium acetate. Twenty-one liters of cultures containing bacterial cells were extracted with acetone, and aqueous acetone extracts were subsequently extracted with EtOAc. The resulting extract was separated by flash column chromatography on silica gel (hexane-EtOAc), and each fraction was subjected to an MTT assay to determine cytotoxicity against B16 melanoma cells. After a two-step purification of the active fractions by HPLC, Compound $\mathbf{1}(6.9 \mathrm{mg})$ was obtained as a cytotoxic substance. Meanwhile, Compounds $2(4.5 \mathrm{mg})$ and $3(17.6 \mathrm{mg})$ were obtained from another fraction.

The molecular formula of enhygromic acid (1) was determined to be $\mathrm{C}_{20} \mathrm{H}_{30} \mathrm{O}_{2}$ by high-resolution electrospray ionization mass spectrometry (ESIMS) analysis using the molecular ion at $m / z 303.2299$ $[\mathrm{M}+\mathrm{H}]^{+}$(calculated for $\mathrm{C}_{20} \mathrm{H}_{31} \mathrm{O}_{2}:$ 303.2319). The infrared (IR) spectrum showed a strong absorption at $1685 \mathrm{~cm}^{-1}$ and a very broad band between 3640 and $2390 \mathrm{~cm}^{-1}$, and the ${ }^{13} \mathrm{C}$ nuclear magnetic resonance (NMR) spectrum displayed the carbonyl carbon signal at $\delta_{\mathrm{C}} 170.2$, suggesting the presence of a carboxy group. The ${ }^{1} \mathrm{H}$ and ${ }^{13} \mathrm{C}$ NMR data are listed in Table 1. The two-dimensional NMR correlations of Compound $\mathbf{1}$ are summarized in Figure 3. Two partial structures, $-\mathrm{CH}_{2}-\mathrm{CH}<$ and $-\mathrm{CH}_{2}-\mathrm{CH}_{2}-\mathrm{CH}-\mathrm{CH}\left(\mathrm{CH}_{3}\right)-\mathrm{CH}_{2}-\mathrm{CH}_{2}-\mathrm{CH}<$, were revealed by DQF-COSY correlations. The connectivity of these substructures and the five quaternary carbons were determined by interpretation of the HMBC spectrum (Figure 3A). The elucidated planar structure of 1 contained a fused tricyclic skeleton linked with an $\alpha$-methylacrylic acid chain (Figure 3). The geometry of the double bond at $\mathrm{C}-2$ was determined to be $E$ on the basis of the NOE correlations of $\mathrm{H}-20 / \mathrm{H}-5$ and $\mathrm{H}-20 / \mathrm{H}-9$, and the lack of the NOE of $\mathrm{H}-3 / \mathrm{H}-20$ (Figure 3B). The relative configuration of $4 S^{*}, 5 S^{*}, 9 R^{*}, 10 R^{*}, 13 S^{*}$ was confirmed from the NOE correlations, displayed in Figure 3B.

Table 1. ${ }^{1} \mathrm{H}(600 \mathrm{MHz})$ and ${ }^{13} \mathrm{C}(150 \mathrm{MHz})$ NMR spectroscopic data for enhygromic acid (1) in DMSO- $d_{6}$.

\begin{tabular}{cccc}
\hline Position & $\delta_{\mathrm{C}}$, Type & $\delta_{\mathbf{H}}(\boldsymbol{J}$ in Hz) & HMBC $^{a}$ \\
\hline 1 & $170.2, \mathrm{C}$ & & \\
2 & $127.2(\mathrm{br}), \mathrm{C}$ & & 4 \\
3 & $145.9(\mathrm{br}), \mathrm{CH}$ & $7.27, \mathrm{~s}$ & 4 \\
4 & $52.2, \mathrm{C}$ & $2.81, \mathrm{brd}(7.1)$ & \\
5 & $46.7, \mathrm{CH}$ & & \\
6 & $148.9, \mathrm{C}$ & $2.08, \mathrm{~m}$ & \\
$7 \mathrm{a}$ & $35.3, \mathrm{CH}_{2}$ & $2.39, \mathrm{dt}(13.1,3.0)$ & \\
$7 \mathrm{~b}$ & & $1.36, \mathrm{~m}$ & \\
$8 \mathrm{a}$ & $21.7, \mathrm{CH}_{2}$ & $1.55 \mathrm{~m}$ & \\
$8 \mathrm{~b}$ & & $2.04, \mathrm{~m}$ & \\
9 & $45.2, \mathrm{CH}$ & $1.55, \mathrm{~m}$ & \\
10 & $31.7, \mathrm{CH}$ & $1.09, \mathrm{~m}$ & \\
$11 \mathrm{a}$ & $29.4, \mathrm{CH}_{2}$ & $1.42, \mathrm{~m}$ & \\
$11 \mathrm{~b}$ & & $1.43, \mathrm{~m} ; 1.45, \mathrm{~m}$ & \\
12 & $21.6, \mathrm{CH}_{2}$ & & \\
13 & $46.9, \mathrm{CH}$ & $1.49, \mathrm{dd}(12.7,3.4)$ & \\
14 & $35.6, \mathrm{C}$ & $1.35, \mathrm{~m}$ & \\
$15 \mathrm{a}$ & $40.6, \mathrm{CH}_{2}$ & $1.92, \mathrm{~m}$ & \\
$15 \mathrm{~b}$ & & $4.76, \mathrm{~s}$ & \\
$16 \mathrm{a}$ & $108.1, \mathrm{CH}_{2}$ & $4.85, \mathrm{~d}(1.5)$ & \\
$16 \mathrm{~b}$ & & $0.76, \mathrm{~d}(6.9)$ & 13,14 \\
17 & $19.6, \mathrm{CH}_{3}$ & $1.00, \mathrm{~s}$ & 14,15 \\
18 & $32.6, \mathrm{CH}_{3}$ & $0.86, \mathrm{~s}$ & $1,2,3$ \\
19 & $26.7, \mathrm{CH}_{3}$ & $1.92, \mathrm{~s}$ & \\
20 & $14.7, \mathrm{CH}_{3}$ & & \\
\hline
\end{tabular}

${ }^{a} \mathrm{HMBC}$ correlations are from proton(s) started to the indicated carbon. 
A

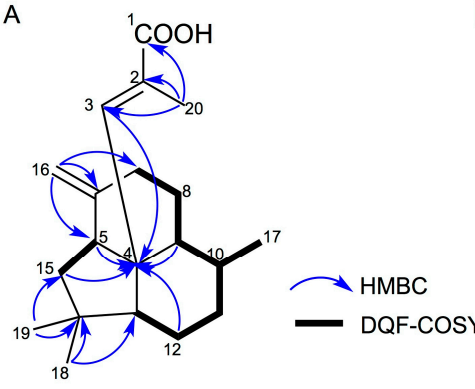

B

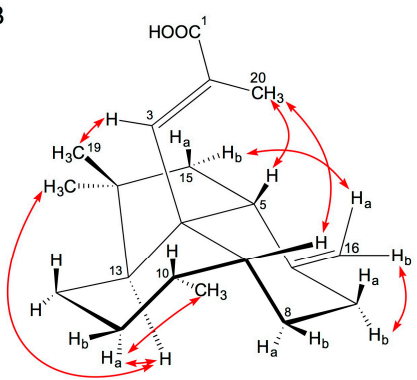

Figure 3. Two-dimensional NMR correlations for 1. (A) DQF-COSY (bold bonds) and HMBC correlations (arrows). (B) Key NOESY correlations (double-headed red arrows).

In order to determine the absolute stereochemistry of $\mathbf{1}$, conformational analysis was conducted by minimizing the energy of all the conformers generated by changing the torsion angle of the C-3-C-4 bond. Only two energy-minimized conformers, A and B, were obtained (Figure 4); the conformer A was more stable than $\mathbf{B}$ by approximately $14 \mathrm{kcal} / \mathrm{mol}$ (Figure S10). Among them, the more stable conformer A was strongly supported by the NOESY correlations (Figure 3B). The circular dichroism (CD) spectrum of $\mathbf{1}$ was subsequently analyzed to determine the spacial relationships between the acrylic acid moiety and the exomethylene group at C-6. On the basis of the splitted negative Cotton effect at $226 \mathrm{~nm}(\Delta \varepsilon-9.0)$ and $196 \mathrm{~nm}(\Delta \varepsilon+8.0)$ (Figure 5) and in conjunction with the above-mentioned conformational analysis, the absolute configuration of $\mathbf{1}$ was determined to be $4 S, 5 S, 9 R, 10 R, 13 S$. Interestingly, the ${ }^{13} \mathrm{C}$ NMR signals of C-2 and C-3 indicated weak and broad signals, suggesting that the free rotation of the methylacrylic acid moiety extending from the center (C-4) of the fused tricyclic core is restricted by the steric repulsion between them. These findings corroborate the uniqueness of the structure of $\mathbf{1}$.

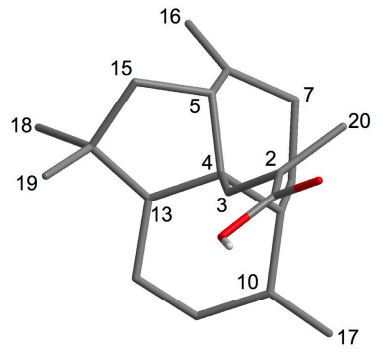

A

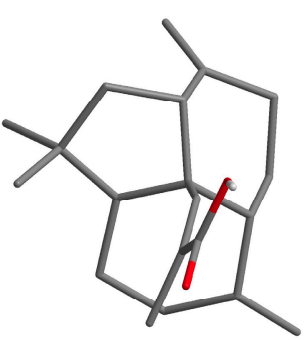

B

Figure 4. Two energy-minimized conformers A and $\mathbf{B}$ of $\mathbf{1 .}$

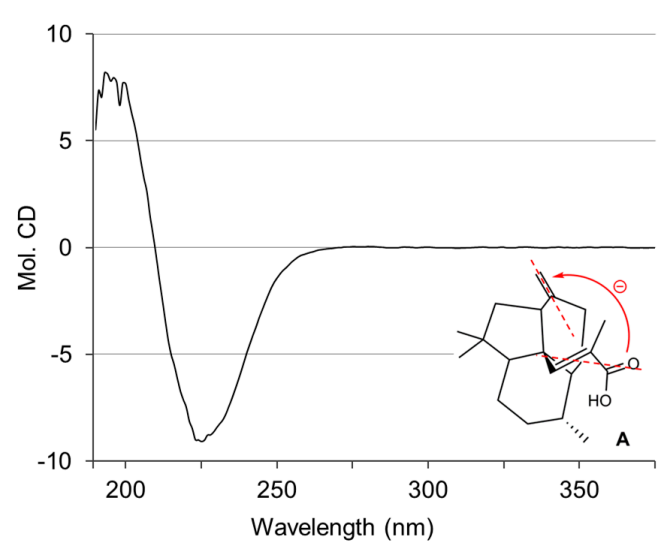

Figure 5. CD spectrum and the lowest energy conformer $\mathbf{A}$ of $\mathbf{1}$. 
Both Compounds 2 and 3 had the molecular formula $\mathrm{C}_{22} \mathrm{H}_{22} \mathrm{O}_{2}$ as determined by high-resolution ESIMS. The IR absorption at $1760-1763 \mathrm{~cm}^{-1}$ suggests that they contain a carbonyl group. Their ${ }^{1} \mathrm{H}$ and ${ }^{13} \mathrm{C}$ NMR data are summarized in Table 2. Three partial structures, two $\mathrm{C}_{6} \mathrm{H}_{5}-$ and a $-\mathrm{CH}_{2}-\mathrm{CH}\left(\mathrm{CH}_{3}\right)_{2}$, were obtained from DQF-COSY correlations of 2 (Figure 6). The connectivity of these substructures, five quaternary carbons $\left(\delta_{C} 127.5,133.8,138.4,149.2\right.$, and 152.0$)$, one carbonyl $\left(\delta_{C} 169.8\right)$, one methylene $\left(\delta_{C} 30.1\right)$, and one $\mathrm{sp}^{2}$ methine $\left(\delta_{C} 109.0\right)$, was determined on the basis of the HMBC correlations (Figure 6), furnishing the planar structure of 2 . The $\mathrm{Z}$ configuration of the $\mathrm{C}-4-\mathrm{C}-5$ double bond was determined by the NOESY correlation between $\mathrm{H}-5$ and $\mathrm{H}-19$. The structure of $\mathbf{3}$ was determined as an isomer of $\mathbf{2}$ in a similar manner to that for $\mathbf{2}$ (Table 2 and Figure 6). In contrast to 2, the geometry of the double bond at C-4 was found to be $E$ because of the lack of NOE correlation between H- 5 and $\mathrm{H}-19$, concluding that 3 is the $E$ isomer of 2. Deoxyenhygrolides A (2) and B (3) are new enhygrolide analogs, where the phenolic groups in enhygrolides [12] are replaced by hydrogen atoms. Although enhygrolide A ( $Z$ isomer) is reported to be more stable than enhygrolide $B$ ( $E$ isomer) and that their isomerization is irreversible [12], we did not observe the isomerization from $\mathbf{3}(E)$ to $\mathbf{2}(Z)$, and the yield of $\mathbf{3}$ was approximately four times that of $\mathbf{2}$. Thus, the phenolic hydroxyl group of enhygrolides may affect the stability of the $E / Z$ isomers for this type of compound.

Table 2. ${ }^{1} \mathrm{H}(400 \mathrm{MHz})$ and ${ }^{13} \mathrm{C}(100 \mathrm{MHz}) \mathrm{NMR}$ spectroscopic data for deoxyenhygrolides $\mathrm{A}(2)$ and $\mathrm{B}(3)$ in $\mathrm{C}_{6} \mathrm{D}_{6}$.

\begin{tabular}{|c|c|c|c|c|c|c|}
\hline \multirow[b]{2}{*}{ Position } & \multicolumn{3}{|c|}{ Deoxyenhygrolide A (2) } & \multicolumn{3}{|c|}{ Deoxyenhygrolode B (3) } \\
\hline & $\delta_{C}$, Type & $\delta_{\mathrm{H}}(J$ in $\mathrm{Hz})$ & $\mathrm{HMBC}^{a}$ & $\delta_{C}$, Type & $\delta_{\mathrm{H}}(J$ in $\mathrm{Hz})$ & $\mathrm{HMBC}^{a}$ \\
\hline 1 & $169.8, \mathrm{C}$ & & & $169.3, \mathrm{C}$ & & \\
\hline 2 & $127.5, \mathrm{C}$ & & & $132.5, \mathrm{C}$ & & \\
\hline 3 & 152.0, C & & & $149.6, \mathrm{C}$ & & \\
\hline 4 & $149.2, \mathrm{C}$ & & & $150.2, \mathrm{C}$ & & \\
\hline 5 & 109.0, $\mathrm{CH}$ & $5.70, \mathrm{~s}$ & $3,4,6,7,11$ & $113.8, \mathrm{CH}$ & $6.58, \mathrm{~s}$ & $3,4,6,7,11$ \\
\hline 6 & $133.8, \mathrm{C}$ & & & 133.7, C & & \\
\hline 7,11 & $130.7, \mathrm{CH}$ & $7.74, \mathrm{~d}(7.5)$ & & $129.5, \mathrm{CH}$ & $6.82, \mathrm{~m}$ & \\
\hline 8,10 & 129.0, CH & $7.12, \mathrm{t}(7.5)$ & & $128.3, \mathrm{CH}$ & $6.96, \mathrm{~m}$ & \\
\hline 9 & $128.7, \mathrm{CH}$ & $7.01, \mathrm{t}(7.5)$ & & $128.0, \mathrm{CH}$ & 6.96, m & \\
\hline 12 & $30.1, \mathrm{CH}_{2}$ & $3.51, \mathrm{~s}$ & $1,2,3,13,14,18$ & $30.2, \mathrm{CH}_{2}$ & $3.56, \mathrm{~s}$ & $1,2,3,13,14,18$ \\
\hline 13 & $138.4, \mathrm{C}$ & & & $138.4, \mathrm{C}$ & & \\
\hline 14,18 & $128.9, \mathrm{CH}$ & $7.18, \mathrm{~d}(7.5)$ & & $128.9, \mathrm{CH}$ & $7.25, \mathrm{~d}(7.5)$ & \\
\hline 15,17 & $128.9, \mathrm{CH}$ & $7.10, \mathrm{t}(7.5)$ & & $128.9, \mathrm{CH}$ & $7.12, \mathrm{t}(7.2)$ & \\
\hline 16 & $126.8, \mathrm{CH}$ & $7.02, \mathrm{t}(7.5)$ & & $126.9, \mathrm{CH}$ & $7.02, \mathrm{t}(7.4)$ & \\
\hline 19 & $33.6, \mathrm{CH}_{2}$ & $1.92, \mathrm{~d}(7.4)$ & $2,3,4$ & $34.8, \mathrm{CH}_{2}$ & $2.00, \mathrm{~d}(7.1)$ & $2,3,4$ \\
\hline 20 & $29.1, \mathrm{CH}$ & 1.55 , non $(6.6)$ & 3 & $28.3, \mathrm{CH}$ & $1.07, \operatorname{non}(6.8)$ & 3 \\
\hline 21,22 & 22.6, $\mathrm{CH}_{3}$ & $0.62, \mathrm{~d}(6.6)$ & & $22.0, \mathrm{CH}_{3}$ & $0.33, \mathrm{~d}(6.6)$ & \\
\hline
\end{tabular}

${ }^{a} \mathrm{HMBC}$ correlations are from proton(s) started to the indicated carbon.

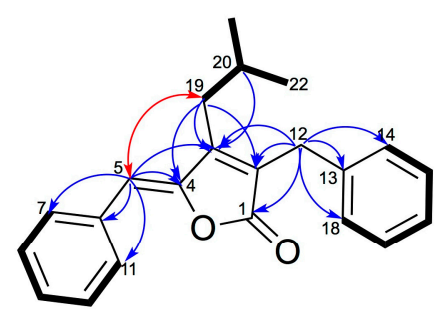

2

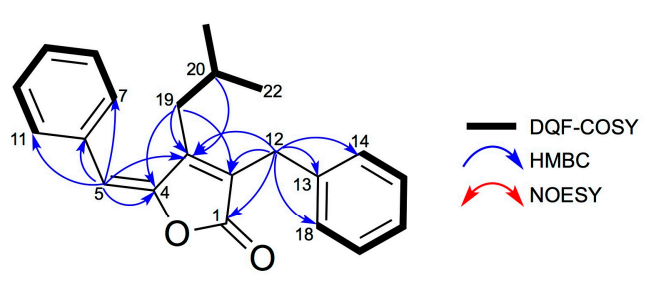

3

Figure 6. Key correlations in two-dimensional NMR spectra of 2 and 3.

\subsection{Bioactivities of $\mathbf{1}-\mathbf{3}$}

Enhygromic acid (1) exhibited cytotoxicity against B16 melanoma cells, and its 50\% inhibitory concentration $\left(I C_{50}\right)$ of $46 \mu \mathrm{M}$ is comparable to that of paclitaxel $(57 \mu \mathrm{M})$ (Figure $\left.7 \mathrm{~A}\right)$. On the other hand, against HeLa-S3 cells, 1 showed no inhibitory activity $\left(I C_{50}>30 \mu \mathrm{M}\right)$ although paclitaxel was 
highly active $\left(I C_{50}=6.0 \mathrm{nM}\right)$. Furthermore, 1 enhanced the nerve growth factor (NGF)-induced neurite outgrowth of PC12 cells. The neurite outgrowth $(22 \%)$ induced by a trace amount $(1 \mathrm{ng} / \mathrm{mL})$ of NGF was enhanced up to $67 \%$ in a dose-dependent manner (Figure 7B). In anti-microbial tests, 1 inhibited the growth of a Gram-positive bacterium, Bacillus subtilis, at a minimum inhibitory concentration (MIC) of $8 \mu \mathrm{g} / \mathrm{mL}$, but was inactive against a Gram-negative bacterium (Escherichia coli), fungi (Candida rugosa, Aspergillus niger, Rhizopus oryzae, and Trichophyton mentagrophytes), and an oomycete (Phytophthora capsici).

A

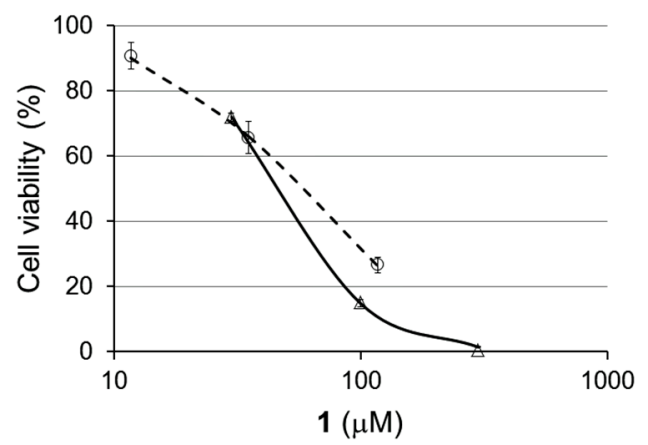

B

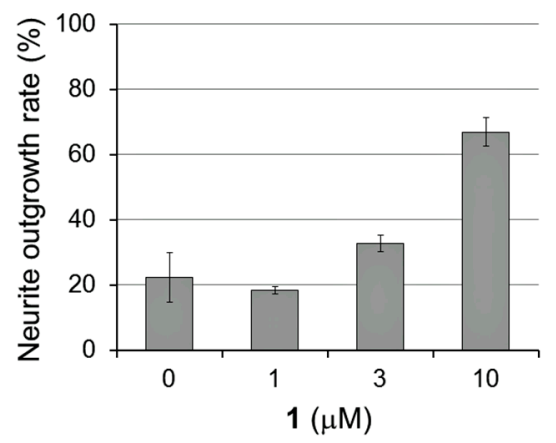

Figure 7. Bioactivities of enhygromic acid (1). (A) Cytotoxicity of $\mathbf{1}$ (open triangles) and paclitaxel (open circles, dotted line) against the B16 melanoma cells. (B) Enhancing activity of NGF-induced neurite outgrowth of PC12 cells.

On the other hand, deoxyenhygrolides A (2) and B (3) did not exhibit any activities in the above-mentioned tests. They are classified into $\gamma$-alkylidenebutenolides, and some structurally related bioactive metabolites were reported, e.g., enhygrolides [12], nostoclides [15], and cyanobacterin [16]. Enhygrolide A, a phenolic congener of 2, was reported to show an antimicrobial activity $(M I C=4 \mu \mathrm{g} / \mathrm{mL})$ against a Gram-positive bacterium, Arthrobacter sp. Nostoclides are chlorinated phenols and showed a moderate cytotoxicity $\left(I C_{50}=10 \mu \mathrm{g} / \mathrm{mL}\right)$ against animal cell lines (Neuro-2a and $\mathrm{KB}$ cells). Cyanobacterin is a chlorinated phenyl ether and is known to inhibit the growth of cyanobacteria and green algae. The lack of the bioactivities of $\mathbf{2}$ and $\mathbf{3}$ suggests that the (halogenated) phenol group(s) may play an important role for the bioactivity of the $\gamma$-alkylidenebutenolides.

\subsection{Putative Biosynthetic Mechanism for $\mathbf{1}$}

Enhygromic acid (1) possesses a unique fused ring structure, decahydroacenaphthylene, which is connected with $\alpha$-methylacrylic acid. The carbon skeleton of $\mathbf{1}$ can be divided into four isoprene units [C-1-C-2(C-20)-C-3-C-4, C-18-C-14(C-19)-C-13-C-12, C-11-C-10(C-17)-C-9-C-8, C-7-C-6(C-16)-C-5-C-15], suggesting that this molecule is a diterpene. However, the connectivity of the first unit C-1-C-2(C-20)-C-3-C-4 is inconsistent with the head-to-tail isoprene rule. Therefore, we propose two putative pathways for the biosynthesis of 1 : (a) $\alpha$-humulene formation from farnesyl diphosphate (FPP) followed by a post-prenylation; or (b) cyclization of geranylgeranyl diphosphate (GGPP) followed by the rearrangement of one isoprenyl unit (Figure 8). The resulting intermediate I undergoes repeated 1,3-hydride shift/cyclization and the oxidation of the terminal methyl group. In silico analysis was carried out on the genome sequences of Enhygromyxa salina DSM 15201 (= E. salina SHK-1 ${ }^{\mathbf{T}}$ in Figure 2) [4] by antiSMASH (ver. 4.0.0) software (http:/ / antismash.secondarymetabolites.org), revealing the presence of seven terpenoid biosynthetic gene clusters, three of which were found to contain a core gene homologous to a terpene (pentalenene) synthase gene. Since pentalenene is known to be biosynthesized from FPP via $\alpha$-humulene (Figure 8 ), one of these genes might be responsible for the biosynthesis of $\mathbf{1}$, and Route a is more plausible than Route b. However, unfortunately, we were unable to find any related genes such as an FPP (or GGPP) synthase gene, a prenyltransferase gene 
(Route a), and oxidase gene(s) inside or around these gene clusters to support the biosynthetic route. The biosynthetic mechanism for the construction of this unique carbon skeleton is to be elucidated by cloning the responsible terpene synthase gene in the future.

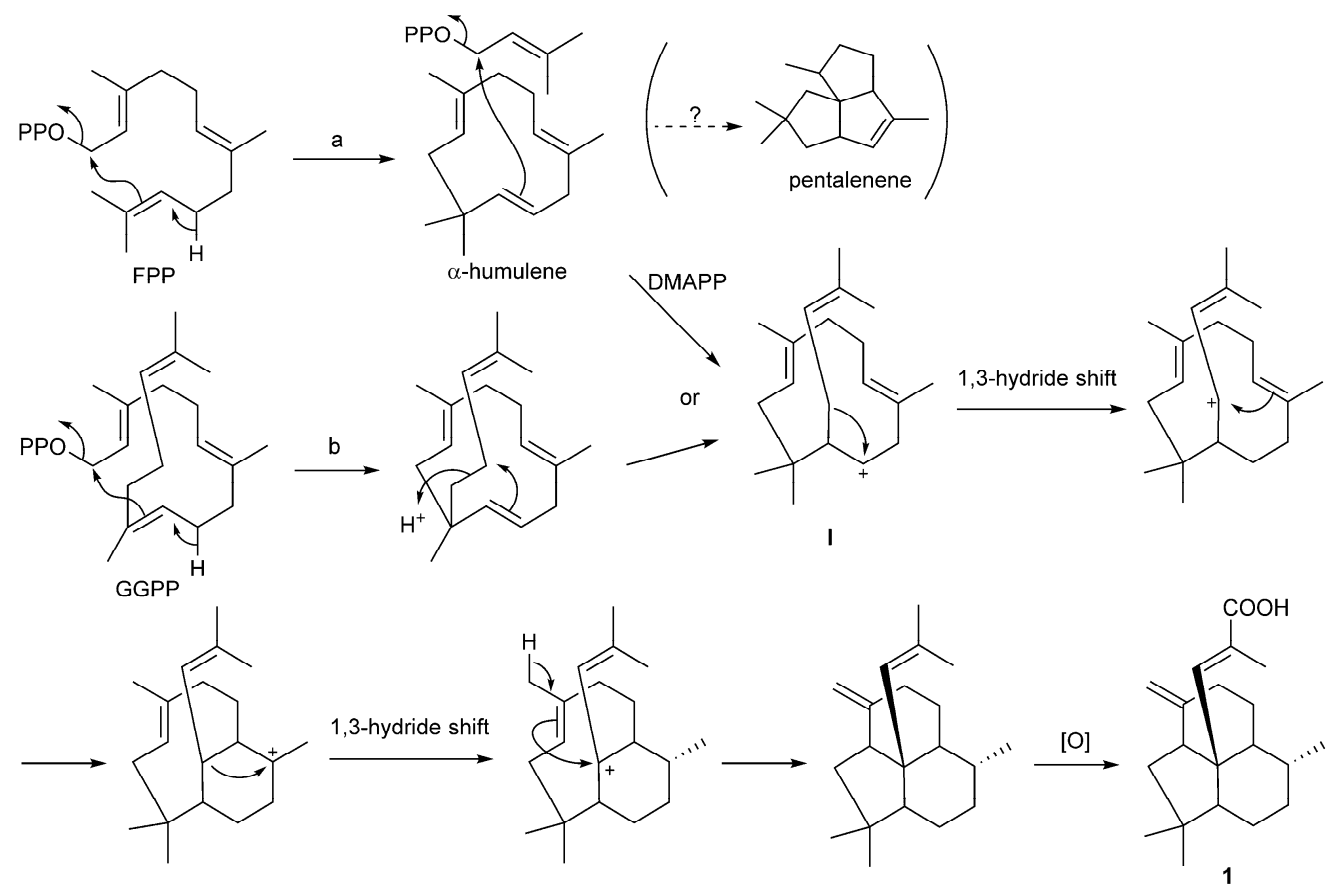

Figure 8. A putative biosynthetic pathway for enhygromic acid (1). The first step would be the cyclization of farnesyl diphosphate (FPP) to $\alpha$-humulene (Route a) or geranylgeranyl diphosphate (GGPP) to a dimethylallylhumulene derivative (Route $b$ ), which are converted to the common cation intermediate $\mathbf{I}$ and led to $\mathbf{1}$ via a series of steps.

\section{Materials and Methods}

\subsection{General Procedures}

IR spectra were measured using an FT/IR-4100 spectrometer (JASCO, Tokyo, Japan). Ultraviolet (UV) spectra were obtained using a V-530 spectrometer (JASCO). CD spectrum was taken on a J-720WN spectrometer (JASCO). Specific rotations were recorded on a DIP-370 spectrometer (JASCO). High-resolution mass spectra (HRMS) were acquired on a Mariner Biospectrometry Workstation (Thermo Fisher Scientific (former Applied Biosystems), Waltham, MA, USA) in the positive electrospray ionization (ESI) mode using $80 \% \mathrm{MeOH}-0.1 \% \mathrm{HCOOH}$ and $80 \% \mathrm{MeOH}-1 \mathrm{mM}$ HCOONa for enhygromic (1) acid and deoxyenhygrolides (2 and 3), respectively, as the infusion solvent. NMR spectra were obtained on an Avance 400 (400 MHz) or Avance III HD 600 Cryo-Probe (600 MHz) spectrometer (Bruker BioSpin, Yokohama, Japan). The chemical shifts (ppm) were referenced to the solvent (DMSO- $d_{6}$ or $\mathrm{C}_{6} \mathrm{D}_{6}$ ) peaks. Flash column chromatography was carried out with a medium-pressure gradient system equipped with a Pump Module C-605 and a Pump Manager C-615 (BÜCHI, Flawil, Switzerland). Preparative high-performance liquid chromatography (HPLC) was performed on a high-pressure gradient system composed of a PU-2087 pump, a DG-2080-53 degasser, an MX-2080-32 mixer, and a UV-2075 detector (JASCO). Melting point was measured on a micro melting point apparatus MP-J3 (Yanaco, Kyoto, Japan).

\subsection{Bacterial Strain}

The myxobacterial strain SNB-1 was isolated from a sand sample collected in September 1998 at a beach in Kashiwazaki, Niigata, Japan $\left(37^{\circ} 22^{\prime} \mathrm{N}, 138^{\circ} 33^{\prime} \mathrm{E}\right)$. The isolation procedure was performed 
according to the method previously described [14]. The strain was cultured and maintained in N1.0-S75-15 agar or VY/2-S75-15 agar [17]. The growth of the strain was observed with $0.0-4.5 \%(w / v)$ $\mathrm{NaCl}$ (optimum, 1.0-2.0\%). The 16S rRNA gene sequence (1505 nt) was deposited under the DDBJ accession number of LC066681. The phylogenetic tree (Figure 2) was constructed with the MEGA6 software by neighbor-joining method (NJ) based on 16S rRNA gene sequences, indicating that the strain SNB-1 belonged to the suborder Nannocystineae, order Myxococcales, in the class Deltaproteobacteria and was most closely related to the type strain of marine myxobacteria, Enhygromyxa salina SHK- $1^{\mathrm{T}}$ with a $97 \%$ similarity (Figure 2). The strain contained menaquinone-7 (MK-7) as the major respiratory quinone. Based on these findings, the strain was identified as a new species of the genus Enhygromyxa, and tentatively designated as Enhygromyxa niigataensis.

\subsection{Isolation of $\mathbf{1}-\mathbf{3}$}

The marine myxobacterium Enhygromyxa sp. SNB-1 was precultured on the VY/2-SWS agar (5 g of Baker's yeast cake, $20 \mathrm{~g}$ of sodium chloride, $0.5 \mathrm{mg}$ of cyanocobalamin, and $15 \mathrm{~g}$ of agar (per liter of Sea Water Salt solution (SWS) [14])) supplemented with $0.1 \%(w / v)$ of sodium acetate for two weeks at $30{ }^{\circ} \mathrm{C}$. The colony was cut into small pieces and inoculated into a $2 \mathrm{~L}$ Erlenmeyer flask containing $750 \mathrm{~mL}$ of VY/4-SWS liquid medium (2.5 g of Baker's yeast cake, $20 \mathrm{~g}$ of sodium chloride, and $0.5 \mathrm{~g}$ of cyanocobalamin (per liter of SWS)) supplemented with $100 \mathrm{mM}$ sodium acetate and gel cube for the bacterial growth promotion, then cultured for three weeks at $30^{\circ} \mathrm{C}$ and $180 \mathrm{rpm}$. A total of $21 \mathrm{~L}$ of cultured broth containing the cells and gel cube was extracted once with $63 \mathrm{~L}$ and then twice with $10.5 \mathrm{~L}$ of acetone. The mixtures were filtered, combined, and then concentrated under reduced pressure. The residual aqueous mixture (a total of $14 \mathrm{~L}$ ) was extracted with EtOAc (a total of $14 \mathrm{~L}$ ). The concentration of the organic layer gave the crude extract $(1.9 \mathrm{~g})$. This extract was chromatographed on a HI-FLASH ${ }^{\mathrm{TM}}$ silica gel column (size $2 \mathrm{~L}, 45 \mathrm{~g}$, Yamazen Co., Osaka, Japan) with a linear gradient of $20-100 \%$ (40 $\mathrm{min})$ EtOAc in hexane at $20 \mathrm{~mL} / \mathrm{min}$. The fractions $(60.1 \mathrm{mg})$ eluted with $34-38 \%$ EtOAc in hexane were combined and subjected to reversed phase HPLC (Develosil ODS-HG-5 (20 i.d. $\times 250 \mathrm{~mm}$, Nomura Chemical Ltd., Seto, Japan), $90-100 \% \mathrm{MeOH}$ (20 min, linear gradient), $8 \mathrm{~mL} / \mathrm{min}$, detection at $220 \mathrm{~nm}$ ). The fraction $(9.3 \mathrm{mg}$ ) eluted at $22-25 \mathrm{~min}$ was further subjected to preparative HPLC (Develosil ODS-HG-5 (20 i.d. $\times 250$ mm, Nomura Chemical Ltd.), $\mathrm{MeOH}-\mathrm{MeCN}-\mathrm{H}_{2} \mathrm{O}$ (42.5:42.5:15), $10 \mathrm{~mL} / \mathrm{min}$, detection at $220 \mathrm{~nm})$ to obtain $6.9 \mathrm{mg}$ of enhygromic acid $\left(1, t_{\mathrm{R}}=41 \mathrm{~min}\right)$. The fraction eluted with $20-34 \%$ EtOAc in hexane in the flash column chromatography were combined and separated by flash column chromatograph (HI-FLASH ${ }^{\mathrm{TM}}$ silica gel column (size M, $14 \mathrm{~g}$ ), 0-25\% EtOAc in hexane (50 min, linear gradient), $6 \mathrm{~mL} / \mathrm{min}$ ). The fractions $(272 \mathrm{mg}$ ) eluted with $7.5-10 \%$ EtOAc in hexane were purified by HPLC (Develosil ODS-HG-5 (20 i.d. $\times 250 \mathrm{~mm}, 80 \% \mathrm{MeOH}$, $9 \mathrm{~mL} / \mathrm{min}$, detection at $315 \mathrm{~nm})$ to afford deoxyenhygrolides $\mathrm{A}\left(2,4.5 \mathrm{mg}, t_{\mathrm{R}}=46 \mathrm{~min}\right)$ and $\mathrm{B}(3$, $\left.17.6 \mathrm{mg}, t_{\mathrm{R}}=38 \mathrm{~min}\right)$.

\subsubsection{Enhygromic Acid (1)}

Colorless powder; $\mathrm{mp} 209-213{ }^{\circ} \mathrm{C}$ (hexane), $[\alpha]_{\mathrm{D}}^{26}-34$ (c 0.06, MeOH); UV (1\% MeOH in MeCN) $\lambda_{\max }(\varepsilon) 223(11,000) \mathrm{nm} ; \mathrm{CD}\left(1 \% \mathrm{MeOH}\right.$ in MeCN) $\lambda_{\text {ext }}(\Delta \varepsilon) 226(-9.0), 196(+8.0) \mathrm{nm}$; IR (film) $v_{\max }$ 3640-2390 (br), 3084, 1685, 888, $757 \mathrm{~cm}^{-1}$; HR ESIMS m/z $303.2299[\mathrm{M}+\mathrm{H}]^{+}$(calcd. for $\mathrm{C}_{20} \mathrm{H}_{31} \mathrm{O}_{2} 303.2319$ ).

\subsubsection{Deoxyenhygrolide A (2)}

Pale yellow oil; UV (MeCN) $\lambda_{\max }(\varepsilon) 229(14,000), 329(32,000) \mathrm{nm}$; IR (film) $v_{\max } 3060,3028,1763$, 1027, $693 \mathrm{~cm}^{-1}$; HR ESIMS $\mathrm{m} / \mathrm{z} 341.1511[\mathrm{M}+\mathrm{Na}]^{+}$(calcd. for $\mathrm{C}_{22} \mathrm{H}_{22} \mathrm{O}_{2} \mathrm{Na} 341.1512$ ).

\subsubsection{Deoxyenhygrolide B (3)}

Colorless oil; UV (MeCN) $\lambda_{\max }(\varepsilon) 299(27,000) \mathrm{nm}$; IR (film) $v_{\max }$ 3060, 3028, 1760, 1040, 723, $699 \mathrm{~cm}^{-1}$; HR ESIMS m/z $341.1499[\mathrm{M}+\mathrm{Na}]^{+}$(calcd. for $\mathrm{C}_{22} \mathrm{H}_{22} \mathrm{O}_{2} \mathrm{Na} 341.1512$ ). 


\subsection{Conformational Analysis}

The conformational analysis of enhygromic acid (1) was performed by Chem3D Ultra in ChemOffice 15.1 package (PerkinElmer Co., Waltham, MA, USA). The dihedral angle C-2-C-3-C-4-C-5 of 1 was rotated by every $15^{\circ}$, and MM2 energy minimization was carried out for all angles to obtain only two local minimum conformers. The result was visualized by a graph of the local minimum energy and angle against the input dihedral angle of C-2-C-3-C-4-C-5 (Figure S10).

\subsection{Cytotoxicity Test}

Cytotoxicity test against HeLa-S3 and B16 melanoma cells followed the methods reported previously $[8,18]$.

\subsection{NGF-Enhancing Activity for PC12 Cells}

Nerve growth factor (NGF)-enhancing activity was evaluated by following the method reported previously [19] with some modifications. Briefly, PC12 cells cultured in DMEM supplemented with $10 \%$ fetal bovine serum (Biosera, Kansas City, MO, USA), 5\% horse serum (Thermo Fisher Scientific Inc., Waltham, MA, USA), and antibiotics (100 $\mu \mathrm{g} / \mathrm{mL}$ streptomycin and 100 units $/ \mathrm{mL}$ penicillin). A total of 15,000 cultured cells in $1 \mathrm{~mL}$ of the same medium were seeded into each well of a 24-well microplate collagen Type I-coated (IWAKI, Tokyo, Japan). After preincubation for $24 \mathrm{~h}$ at $37^{\circ} \mathrm{C}$ in an atmosphere of $5 \% \mathrm{CO}_{2}$, the medium was replaced with $1 \mathrm{~mL}$ of the serum-free DMEM containing $0.5 \mathrm{ng} / \mathrm{mL}$ NGF (PeproTech, Rocky Hill, NJ, USA) and a compound in $5 \mu \mathrm{L}$ DMSO. The morphological change of the cells was monitored by an inverted microscope FSX100 (OLYMPUS, Tokyo, Japan) after 4 days of incubation. A field that covers approximately 100 cells was randomly chosen and the number of the cells bearing neurite outgrowth longer than the cell diameter was counted. The data were the mean \pm SD of triplicate.

\subsection{Anti-Phytophthora Assay}

The growth inhibitory activity against the oomycete Phytophthora capsici was evaluated by following the method reported previously [8].

\subsection{MIC Assay}

All microorganisms, E. coli AJ 3837 (NBRC 14237), B. subtilis AJ 12865 (ATCC 6051), C. rugosa AJ 14513 (NBRC 0750), A. niger AJ 117065 (ATCC 10864), R. oryzae AJ 117321 (JCM 5582), and T. mentagrophytes AJ 117161 (NBRC 7522), were provided by the Institute for Innovation, Ajinomoto Co., Inc. (Kanagawa, Japan). Antibacterial tests against E. coli and B. subtilis followed the reported protocol [20]. Antifungal activity was evaluated by following the reported methods [21-23]. The tests were carried out at the concentrations of $1,2,4,8,16,32$, and $64 \mu \mathrm{g} / \mathrm{mL}$ for bacteria or $0.5,1,2,4,8,16$, and $32 \mu \mathrm{g} / \mathrm{mL}$ for fungi.

\section{Conclusions}

Three new compounds, enhygromic acid (1) and deoxyenhygrolides (2 and 3), were isolated from a new marine myxobacterial species of the genus Enhygromyxa, and the absolute configuration of 1 was determined by NOESY and CD spectrum. As regards the results of the biological tests, 1 showed the cytotoxicity against B16 melanoma cells, NGF neurite outgrowth promoting activity to PC12 cells, and growth inhibition against B. subtilis. On the other hand, 2 and $\mathbf{3}$ did not show any biological activities in this study. Compound $\mathbf{1}$ has a quite unique and rare acrylic acid derivative with a decahydroacenaphthylene skeleton, which had not been reported prior to this study. Therefore, 1 will be noticed in the field of organic synthesis or biosynthesis research in the future. 
Supplementary Materials: The following are available online at www.mdpi.com/1660-3397/15/4/109/s1: Figure S1: ${ }^{1} \mathrm{H}$ NMR spectrum of $1\left(600 \mathrm{MHz}, \mathrm{DMSO}-d_{6}\right)$, Figure S2: ${ }^{13} \mathrm{C}$ NMR spectrum of $\mathbf{1}\left(150 \mathrm{MHz}, \mathrm{DMSO}-d_{6}\right)$, Figure S3: DQF-COSY of $1\left(600 \mathrm{MHz}, \mathrm{DMSO}-d_{6}\right)$, Figure S4: HSQC spectrum of $1\left(600 \mathrm{MHz}, \mathrm{DMSO}-d_{6}\right)$, Figure S5: HMBC spectrum of $1\left(600 \mathrm{MHz}\right.$, DMSO- $\left.d_{6}\right)$, Figure S6: NOESY of $1\left(600 \mathrm{MHz}\right.$, DMSO- $\left.d_{6}\right)$, Figure S7: UV spectrum of 1, Figure S8: IR spectrum of 1, Figure S9: ESI-TOF-MS (+) spectrum of 1, Figure S10: Local minimum energy (orange line) and dihedral angle $\mathrm{C} 2-\mathrm{C} 3-\mathrm{C} 4-\mathrm{C} 5$ (blue dotted line) against the input dihedral angle in 1, Figure S11: ${ }^{1} \mathrm{H}$ NMR spectrum of $2\left(400 \mathrm{MHz}, \mathrm{C}_{6} \mathrm{D}_{6}\right)$, Figure S12: ${ }^{13} \mathrm{C}$ NMR spectrum of $2\left(100 \mathrm{MHz}, \mathrm{C}_{6} \mathrm{D}_{6}\right)$, Figure S13: DQF-COSY of 2 (400 MHz, C $\left.{ }_{6} \mathrm{D}_{6}\right)$, Figure S14: HSQC spectrum of 2 (400 MHz, $\left.{ }_{6} \mathrm{D}_{6}\right)$, Figure S15: HMBC spectrum of $2\left(400 \mathrm{MHz}, \mathrm{C}_{6} \mathrm{D}_{6}\right)$, Figure S16: NOESY of $2\left(400 \mathrm{MHz}, \mathrm{C}_{6} \mathrm{D}_{6}\right)$, Figure S17: UV spectrum of 2, Figure S18: IR spectrum of 2, Figure S19: ESI-TOF-MS spectrum of 2, Figure S20: ${ }^{1} \mathrm{H}$ NMR spectrum of $3\left(400 \mathrm{MHz}, \mathrm{C}_{6} \mathrm{D}_{6}\right)$, Figure S21: ${ }^{13} \mathrm{C}$ NMR spectrum of $3\left(100 \mathrm{MHz}, \mathrm{C}_{6} \mathrm{D}_{6}\right)$, Figure S22: DQF-COSY of $3\left(400 \mathrm{MHz}, \mathrm{C}_{6} \mathrm{D}_{6}\right)$, Figure S23: HSQC spectrum of $3\left(400 \mathrm{MHz}, \mathrm{C}_{6} \mathrm{D}_{6}\right)$, Figure S24: HMBC spectrum of $3\left(400 \mathrm{MHz}, \mathrm{C}_{6} \mathrm{D}_{6}\right)$, Figure S25: NOESY of 3 (400 MHz, $\mathrm{C}_{6} \mathrm{D}_{6}$ ), Figure S26: UV spectrum of 3, Figure S27: IR spectrum of 3, Figure S28: ESI-TOF-MS spectrum of 3 .

Acknowledgments: We are grateful to Kin-ichi Oyama at Chemical Instrumentation Facility of the Research Center for Materials Science, Nagoya University, for the measurement of CD, Kazushi Koga at Technical Center of Nagoya University for the measurement of NMR, and Genji Imokawa for providing B16 melanoma cells.

Author Contributions: T.T. isolated the compounds, performed the bioassay and prepared the manuscript. S.N. performed the bioassay. S.Y. cultured the myxobacterium. T.I. and R.F. cultured myxobacterium and performed the phylogenetic analysis. M.O. designed the project and wrote the manuscript.

Conflicts of Interest: The authors declare no conflict of interest.

\section{References}

1. Reichenbach, H. The ecology of the myxobacteria. Environ. Microbiol. 1999, 1, 15-21. [CrossRef] [PubMed]

2. Wenzel, S.C.; Müller, R. The biosynthetic potential of myxobacteria and their impact on drug discovery. Curr. Opin. Drug Discov. Dev. 2009, 12, 220-230.

3. Weissman, K.J.; Müller, R. A brief tour of myxobacterial secondary metabolism. Bioorg. Med. Chem. 2009, 17, 2121-2136. [CrossRef] [PubMed]

4. Dávila-Céspedes, A.; Hufendiek, P.; Crüsemann, M.; Schäberle, T.F.; König, G.M. Marine-derived myxobacteria of the suborder Nannocystineae: An underexplored source of structurally intriguing and biologically active metabolites. Beilstein J. Org. Chem. 2016, 12, 969-984. [CrossRef] [PubMed]

5. Komaki, H.; Fudou, R.; Iizuka, T.; Nakajima, D.; Okazaki, K.; Shibata, D.; Ojika, M.; Harayama, S. PCR detection of type I polyketide synthase genes in myxobacteria. Appl. Environ. Microbiol. 2008, 74, 5571-5574. [CrossRef] [PubMed]

6. Fudou, R.; Iizuka, T.; Yamanaka, S. Haliangicin, a novel antifungal metabolite produced by a marine myxobacterium 1. Fermentation and biological characteristics. J. Antibiot. 2001, 54, 149-152. [CrossRef] [PubMed]

7. Fudou, R.; Iizuka, T.; Sato, S.; Ando, T.; Shimba, N.; Yamanaka, S. Haliangicin, a novel antifungal metabolite produced by a marine myxobacterium 2. Isolation and structural elucidation. J. Antibiot. 2001, 54, $153-156$. [CrossRef] [PubMed]

8. Sun, Y.; Tomura, T.; Sato, J.; Iizuka, T.; Fudou, R.; Ojika, M. Isolation and biosynthetic analysis of haliamide, a new PKS-NRPS hybrid metabolite from the marine myxobacterium Haliangium ochraceum. Molecules 2016, 21, 59. [CrossRef] [PubMed]

9. Iizuka, T.; Fudou, R.; Jojima, Y.; Ogawa, S.; Yamanaka, S.; Inukai, Y.; Ojika, M. Miuraenamides A and B, novel antimicrobial cyclic depsipeptides from a new slightly halophilic myxobacterium: Taxonomy, production, and biological properties. J. Antibiot. 2006, 59, 385-391. [CrossRef] [PubMed]

10. Ojika, M.; Inukai, Y.; Kito, Y.; Hirata, M.; Iizuka, T.; Fudou, R. Miuraenamides: Antimicrobial cyclic depsipeptides isolated from a rare and slightly halophilic myxobacterium. Chem. Asian J. 2008, 3, 126-133. [CrossRef] [PubMed]

11. Felder, S.; Dreisigacker, S.; Kehraus, S.; Neu, E.; Bierbaum, G.; Wright, P.R.; Menche, D.; Schäberle, T.F.; König, G.M. Salimabromide: Unexpected chemistry from the obligate marine myxobacterium Enhygromyxa salina. Chem. Eur. J. 2013, 19, 9319-9324. [CrossRef] [PubMed]

12. Felder, S.; Kehraus, S.; Neu, E.; Bierbaum, G.; Schäberle, T.F.; König, G.M. Salimyxins and enhygrolides: Antibiotic, sponge-related metabolites from the obligate marine myxobacterium Enhygromyxa salina. ChemBioChem 2013, 14, 1363-1371. [CrossRef] [PubMed] 
13. Schäberle, T.F.; Goralski, E.; Neu, E.; Erol, O.; Hölzl, G.; Dörmann, P.; Bierbaum, G.; König, G.M. Marine myxobacteria as a source of antibiotics-comparison of physiology, polyketide-type genes and antibiotic production of three new isolates of Enhygromyxa salina. Mar. Drugs 2010, 8, 2466-2479.

14. Iizuka, T.; Jojima, Y.; Fudou, R.; Yamanaka, S. Isolation of myxobacteria from the marine environment. FEMS Microbiol. Lett. 1998, 169, 317-322. [CrossRef] [PubMed]

15. Yang, X.; Shimizu, Y.; Steiner, J.R.; Clardy, J. Nostoclide I and II, extracellular metabolites from a symbiotic cyanobacterium, Nostoc sp., from the lichen Peltigera canina. Tetrahedron Lett. 1993, 34, 761-764. [CrossRef]

16. Mason, C.P.; Edwards, K.R.; Carlson, R.E.; Pignatello, J.; Gleason, F.K.; Wood, J.M. Isolation of chlorine-containing antibiotic from the freshwater cyanobacterium Scytonema hofmanni. Science 1982, 215, 400-402. [CrossRef] [PubMed]

17. Iizuka, T.; Jojima, Y.; Hayakawa, A.; Fujii, T.; Yamanaka, S.; Fudou, R. Pseudenhygromyxa salsuginis gen. nov., sp. nov., a myxobacterium isolated from an estuarine marsh. Int. J. Syst. Exol. Microbiol. 2013, 63, 1360-1369. [CrossRef] [PubMed]

18. Han, C.; Furukawa, H.; Tomura, T.; Fudou, R.; Kaida, K.; Choi, B.K.; Imokawa, G.; Ojika, M. Bioactive maleic anhydrides and related diacids from the aquatic hyphomycete Tricladium castaneicola. J. Nat. Prod. 2015, 78, 639-644. [CrossRef] [PubMed]

19. Qi, J.; Ojika, M.; Sakagami, Y. Linckosides A and B, two new neuritogenic steroid glycosides from the Okinawan starfish Linckia laevigata. Bioorg. Med. Chem. 2002, 10, 1961-1966. [CrossRef]

20. Clinical and Laboratory Standards Institute. Methods for Dilution Antimicrobial Susceptibility Tests for Bacteria that Grow Aerobically; Approved Standard Ninth Edition, M07-A9; CLSI: Wayne, PA, USA, 2012.

21. National Committee for Clinical Laboratory Standards. Reference Method for Broth Dilution Antifungal Susceptibility Testing of Yeasts; Approved Standard Second Edition, M27-A2; NCCLS: Wayne, PA, USA, 2002.

22. European Committee on Antimicrobial Susceptibility Testing. Methods for the Determination of Broth Dilution Minimum Inhibitory Concentrations of Antifungal Agents for Conidia Forming Moulds; EUCAST, 2014. Available online: http:/ / www.eucast.org/ (accessed on 6 April 2017).

23. Da Silva Barros, M.E.; de Assis Santos, D.; Hamdan, J.S. Evaluation of susceptibility of Tricophyton mentagrophytes and Trichophyton rubrum clinical isolates to antifungal drugs using a modified CLSI microdilution method (M38-A). J. Med. Microbiol. 2007, 56, 514-518. [CrossRef] [PubMed] 